\title{
Biodiversity Conservation in Agricultural Landscapes: the Importance of the Matrix
}

\author{
Patricia Dias Tavares ${ }^{1}$ (D), Mariella Camardelli Uzêda ${ }^{2}$ (D), \\ Alexandra dos Santos Pires ${ }^{3}$ (D) \\ ${ }^{1}$ Instituto Federal de Educação, Ciência e Tecnologia de Goiás, Goiás, Brasil \\ ${ }^{2}$ Empresa Brasileira de Pesquisa Agropecuária (Embrapa Agrobiologia) Seropédica, RJ, Brasil \\ ${ }^{3}$ Universidade Federal Rural do Rio de Janeiro (UFRRJ), Rio de Janeiro, RJ, Brasil
}

\begin{abstract}
Agricultural matrices can lead to landscape homogenization, culminating in losses of biodiversity and ecosystem services. Agricultural management is determinant for developing conservation strategies. In this review, we discuss the influence of the agricultural matrix on biodiversity at different scales. Intensive agriculture under agrochemicals and synthetic fertilizers aggravates forest fragmentation processes, compromising conservation habitats. On the other hand, managed matrixes with greater agricultural biodiversity and reduced synthetic inputs tend to favor species' persistence. There is discord regarding the best model to conserve biodiversity in agricultural landscapes, but the land sharing system increases the landscape heterogeneity, ensures food production, and constitutes a safer approach from the socioecological perspective. Future studies should consider the matrix identity and management to assess fragmentation effects and its ability to harbor biodiversity.
\end{abstract}

Keywords: edge effects, land sharing, land sparing. 


\section{INTRODUCTION}

One of the major challenges of the $21^{\text {st }}$ century is producing food combined with minimizing environmental damage. In the tropics, $83 \%$ of the agricultural production areas originated from forest conversion only in the period from 1980-2000 (Gibbs et al., 2010). About $40 \%$ of the land surface was modified for developing agricultural activities, while only $12 \%$ of the area was destined to nature protection (Foley et al., 2005; Perfecto \& Vandermeer, 2010; Ramankutty et al., 2008). Forest area reduction has raised concerns mainly regarding landscape homogenization (Verburg et al., 2013), losses in biodiversity (Barlow et al., 2016) and reduced ecosystem services (Laurance et al., 2014).

In many regions of the world, the only remaining natural habitats are fragments embedded in landscapes dominated by agriculture. The proportion between agricultural land and forests in Asia and Europe is $(52 \%, 19 \%)$ and $(21 \%, 46 \%)$, respectively (FAO, 2016). In global terms, agriculture occupies $37.7 \%$ of the land, and the forest areas and "other" uses have only 30.7\% and $31.6 \%$, respectively. Forests are still a constant target of land conversion in the tropical domain. In Latin America, $90 \%$ of forest conversion was for agricultural expansion (FAO, 2016; Hosonuma et al., 2012).

It is necessary to consider that there are different forms of agriculture, and that they have different roles for biodiversity and land conservation. Large-scale commercial agriculture is identified as the major precursor of land conversion (Hosonuma et al., 2012), soil degradation (FAO, 2011) and loss of biodiversity (Laurance et al., 2014), when compared to small agriculture. Thus, the identity, configuration and management of agricultural matrices can affect biodiversity differently, with strategic areas for investment in actions aimed at the conservation at different scales.

Agricultural areas composed of biodiversity systems can provide greater landscape heterogeneity and consequently greater resource availability for maintaining biodiversity over time and space. In this sense, agricultural matrices play a decisive role in consolidating structure and sustainable operation of the landscapes (Forman, 1995; Hanski \& Ovaskainen, 2003; Lindenmayer \& Franklin, 2002; Ricketts, 2001).

In this study, the influence of the agricultural matrix on biodiversity at different analysis scales is reviewed: the forest fragments, the edges of the fragments, the matrix itself and the landscape.

\section{MATRIX: DEFINITION AND RELATED CONCEPTS}

The matrix has already been considered as the functionally dominant unit of the landscape (Forman, 1995; Forman \& Grodon, 1986), a concept that presupposes a clear distinction between habitat fragments and the matrix, with a certain homogeneity of the latter. This definition, however, became limited as it made difficult to understand the role of the matrix as a secondary habitat and its influence on the biodiversity of forest fragments. A second definition was proposed by Lindenmayer \& Franklin (2002), where the matrix is understood as the set of non-habitat areas or where the original habitat has already been modified, having lost quality or its capacity to host the studied species.

The matrix can influence the dispersal capacity of the species within the landscape (Kennedy \& Marra, 2010), the persistence of native species in forest fragments (Dallimer et al., 2012; Prevedello \& Vieira, 2010; Viveiros de Castro \& Fernandez, 2004) and the extension of the edge effects (Driscoll \& Donovan, 2004), in addition to intensifying disturbances in forest fragment areas (Hobbs, 2001; Laurance \& Cochrane, 2001; Peres, 2001).

In this study, we call agricultural matrix areas where anthropic activities related to agriculture, livestock and forestry are developed, therefore, agroecosystems with different compositions and management forms.

\section{INFLUENCE ON FOREST REMNANTS}

Forest fragments were compared to "islands" for many years because in most cases they were structurally different from the matrix in which they were inserted. This approach was influenced by the publication of the theory of island biogeography (MacArthur \& Wilson, $1963,1967)$, and has become central to the conservation biology. In this view, forest fragments or habitats and their characteristics, such as size and isolation degree, were considered the main predictors of species' richness (Fahrig, 2013). However, with the evolution in knowledge about habitat loss and fragmentation, the importance of the matrix for maintaining species' 
richness and abundance in the fragments was widely recognized (Laurance, 2008).

There is a strong interaction between habitat remnants and the other units that make up the landscape. The contrast between the remaining areas and the type of surrounding matrix, as well as the developed management forms are determinant factors of the matrix effects on the populations and communities of the species in forest fragments (Kennedy \& Marra, 2010; Perfecto \& Vandermeer, 2010). In the case of agricultural landscapes, the use of agrochemicals and mineral fertilizers, the grazing level and the pressure of invasive species can severely degrade the fragments (Didham et al., 2015).

The use of agricultural inputs promotes effects that extrapolate the agricultural system, influencing natural areas at different scales of the landscape (Didham et al., 2015), as presented in Figure 1. One of the main aspects evidenced by agriculture intensification is the accumulation of nutrients in the remnants of natural habitats (Gardner et al., 2007; Marshall \& Moonen, 2002; Monadjem \& Garcelon, 2005), especially when the fragments are very small. This results in altering the soil properties, mainly compaction, $\mathrm{pH}$ increase, reduced carbon/nitrogen ratio, nitrogen saturation, and an increase of phosphorus, in addition to contamination by heavy metals (Laliberté \& Tylianakis, 2012).

In a study in Atlantic Forest areas in Southeastern Brazil, Uzêda et al. (2016) evaluated the effect of soil eutrophication on the arboreal species community of fragments located in agricultural landscapes. In this study, the authors classified the environment of the fragments as being of intensive use (corn rotated with cassava, the use of chemical fertilizers and pesticides, and soil preparation) or extensive (pasture), and found calcium contents about seven times higher in the sites adjacent to intensive use when compared to fragments adjacent to extensive use. Phosphorus levels were 1.5 to 2.5 times higher in the small and medium fragments adjacent to intensive use areas. The study also indicates that the increase in the phosphorus, potassium and calcium contents can cause changes in the tree species community.

The increase of productivity caused by the entry of nutrients into the fragments influences the composition of species in them, generally leading to reduced plant richness and changes in the composition of other organisms (Honnay et al., 2002; Kleijn \& Snoeijing, 1997; Marrs, 1993). Favoring some species to the detriment of others can reduce the stability and resilience of the remnants, making them more susceptible to invasion of species adapted to other environments and/or exotic species (Didhan et al., 2015; Honnay et al., 2002; Kleijn \& Snoeijing, 1997). Thus, favoring tolerant species to these changes can compromise the quality of forest remnants, leading to a predominance of systems in initial stages of succession, a phenomenon called "retrosuccession" (Lôbo et al., 2011; Melo et al., 2013; Tabarelli et al., 2010).

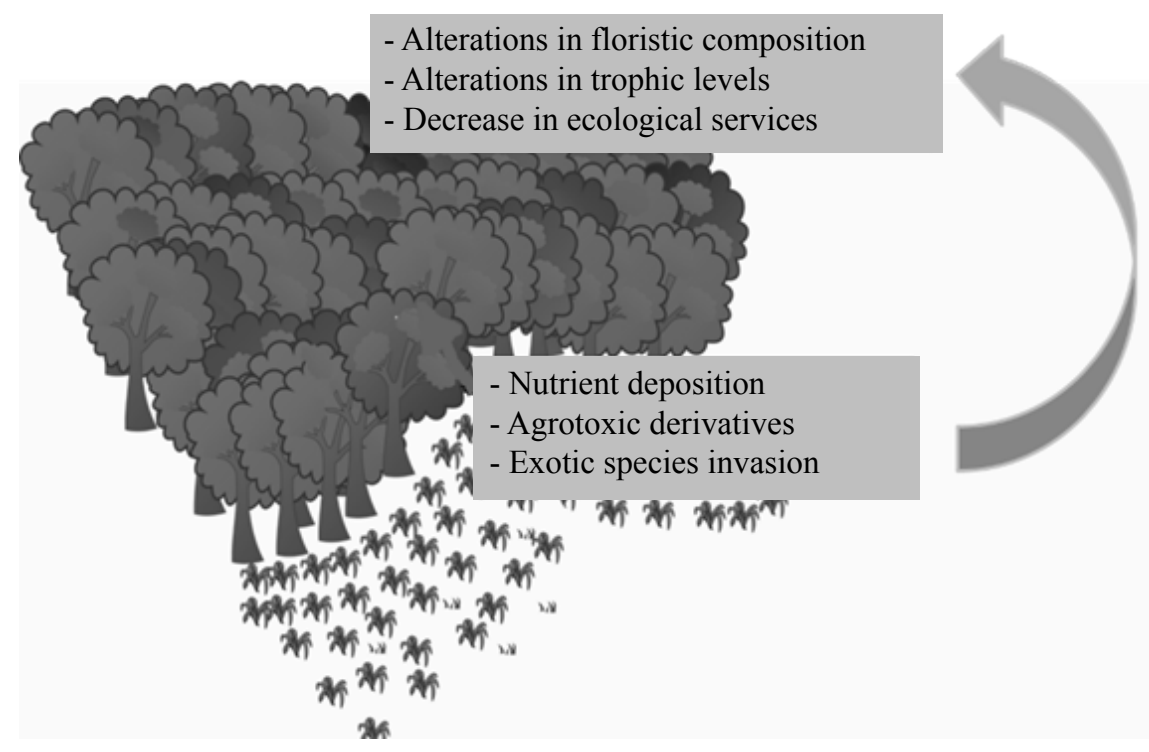

Figure 1. Direct and indirect influences of intensive agriculture on natural vegetation remnants. 
Some studies have also reported the damage caused by the use of airborne pesticides to soil, water and air contamination, as well as the reduction of species diversity in forest fragments, including in areas of conservation units (Kleijn \& Snoeijing, 1997; Öckinger et al., 2012). A study in the Itatiaia National Park (RJ) and São Joaquim National Park (SC) reported that air and water at an altitudinal gradient are contaminated with organochlorine residues of agrochemicals (Meire et al., 2012).

Intensive management with the use of fertilizers, agrochemicals and soil rotation in the matrix can also influence different animal groups present in the fragments. In a study comparing the diversity and abundance of terrestrial amphibians in semi-deciduous forest fragments in Southeastern Brazil, D’Anunciação et al. (2013) found about seven times fewer amphibians in fragments with sugar cane than in pasture. The authors attributed these results to the more intensive management of sugarcane, which is carried out through annual cutting, controlled burning and intense pesticide use that affect the amphibian community directly.

Negative effects have also been reported in groups that act as important ecological service providers, such as pollinators. Through a meta-analysis, Montero-Castaño \& Vilá (2012) demonstrated that the disturbances promoted in the agricultural matrix reduced pollinator diversity and activity, and that this factor was more important than the size of the fragments. The authors concluded that, when the matrix becomes more hostile, pollinators become more vulnerable and have fewer visits, probably due to a decrease in their abundance. In intensively managed agricultural areas there was a reduction in the abundance of pollinators up to $150 \mathrm{~m}$ into the interior of the fragments (Kohler et al., 2008).

Regarding the abovementioned information, it is possible to perceive that the activities developed in the agricultural matrix have effects that reverberate in the remaining areas, which has been called spillover. Blitzer et al. (2012) synthesized this relationship of managed areas "overflowing" to natural vegetation systems from published studies into five important functional groups (herbivores, pathogens, pollinators, predators and seed dispersers). The authors demonstrated that the number of studies that analyzed this effect was less than five per trophic group. Thus, they suggest that the spillover of managed areas to natural areas has been underestimated.
With continued habitat modification resulting in increasingly fragmented landscapes, spillover effects may increase due to the use of intensive activities and lead to more severe degradation processes. It is necessary to consider that these regions can be compromised even with the maintenance of natural habitat areas for conservation, depending on the management developed in the surrounding matrix (Didhan et al., 2015). Landuse patterns over time can promote negative effects on soil processes in border/edge areas that extend into the fragments and are potentially irreversible (Dupouey et al. 2002; Flinn \& Marks, 2007). Therefore, special attention should be directed to the edges, which is the fragment environment immediately affected by the matrix disturbances. These zones can act as mitigators of the matrix influences on forest remnant interiors.

\section{MATRIX FRAGMENT INTERFACE: EDGE EFFECTS}

Edge effects are the main promoters of many changes in fragmented landscapes and represent an inevitable and important consequence of habitat loss and fragmentation (Laurance et al., 2007). These effects occur at the interface between the natural vegetation remnant and the surrounding matrix, and are described as physical and biological changes (Murcia, 1995; Saunders et al., 1991). Due to these changes, there is the formation of an inner-edge gradient of environmental variables, biological composition and structural complexity (Harper et al., 2005; Laurence et al., 2002).

Despite the recognized role played by the surrounding matrix in mediating ecological processes within habitat fragments (Fagan et al., 1999), it is surprising that matrix parameters are often overlooked in edge effects studies. Most studies that evaluate these effects use the penetration of effects as a response variable, without explicitly considering the identity and influence of the adjacent matrix (Ewers et al., 2006; Ries et al., 2004). The intensification of edge effects through the matrix is mainly due to two characteristics of the agricultural systems: a) species composition; and b) management intensity (use of inputs, mainly synthetic fertilizers, agrochemicals and transgenic seeds, land, grazing, among others) (Didham et al., 2015; Rodenhouse et al., 1995).

In the case of abiotic effects, the matrix composition will define the level of structural contrast between the 
surrounding matrix and the natural vegetation fragment. The structural contrast will determine whether the edges will be abrupt or gradual. These differences influence the microclimatic changes (incidence of light, wind and temperature variation) that usually occur in the remnant edges (Cadenasso \& Pickett, 2000; Didham \& Lawton, 1999).

Gradual edges aid in the decelerating and deflecting of wind flow, inducing lower wind speed and less turbulence in the lower part of the forest canopy (Magura, 2002; Wermelinger et al., 2007; Wuyts et al., 2009). Wuyts et al. (2009) evaluated the attenuating effect of gradient edges on the atmospheric deposition of inorganic nitrogen $(\mathrm{N})$ and other potential acidifying pollutants. The study was conducted on three different types of edges (open, abrupt and gradual). There were differences in $\mathrm{N}+\mathrm{S}$ interception between the edges, where the gradient edges intercepted on an average of 80 to $100 \%$ of the residues in winter and summer, respectively.

In relation to the biotic effects, the biodiversity level in the composition of the productive systems also influences the species composition and their interactions in the habitat fragments. In a study in South Africa, Hurst et al. (2013) reported that sugar cane areas promoted reductions in the richness and heterogeneity of small mammal species, increasing similarity and promoting a more homogenized community. Agricultural practices seem to favor communities with high generalist species density, while isolating specialist species (Hurst et al., 2013).

On the other hand, productive systems with greater diversity and structural similarity to the remaining areas may be important to minimize edge effects for some organisms. This was found by Santos-Barrera \& Urbina-Cardona (2011) for amphibians in agroforestry coffee plantations in Mexico. The authors reported that the diversity and abundance of amphibians in the forest mainly depended on the type of matrix adjacent to the forest fragments. Areas with shaded coffee were preferred over planted corn areas, and these results were attributed to the maintenance of native forest tree elements, low management rate and less disturbance intensity in coffee plantations than in corn lots. Areas with shaded coffee reduced edge effects, improved connectivity between the fragments, and increased habitat quality for inland forest amphibian species (Santos-Barrera \& Urbina-Cardona, 2011).
In spite of the importance of structural similarity to diversity (Prevedello \& Vieira, 2010), structurally similar matrices may have distinct influences on the composition of native species communities (Kennedy \& Marra, 2010). Thus, caution is required when considering matrix permeability or making predictions about community responses to edges by only using this factor (Pe'er et al., 2011). Analyzing the variation of edge diversity should also consider the available resources in the matrix (Vanreusel \& Van Dyck, 2007), the functionality and the potential complementarity of the different habitats according to the species needs (Levanoni et al., 2010; Pe'er et al., 2011; Walker et al., 2003). Management practices are therefore determinant for maintaining biodiversity levels, structural contrast, and the amount of chemical inputs, which influence colonization dynamics and plant extinction along the edges (Didham et al., 2015; Frost et al., 2015).

Agricultural management using transgenic varieties increased globally, with the highest increase in Brazil (3.7 million hectares) (ISAAA, 2016). The effects of transgenic plants on non-target organisms are still highly controversial. However, it is important to consider that the use of transgenic varieties can intensify fragmentation processes (Campos \& Hernández, 2015). An edge-border study comparing matrices with conventional and transgenic corn showed that communities of dung beetles on transgenic GM corn edges are affected by chronic exposure to Bt toxin and/ or their ingestion (Campos \& Hernandez, 2015). Such changes have not diminished community diversity, but are promoting changes in the distribution of functional groups, suggesting that the role of these organisms in ecosystems may change. Thus, in the South of Brazil, management with genetically modified corn can accelerate diversity loss in the Atlantic Forest areas, and consequently important ecosystem services provided by dung beetles may be lost (Campos \& Hernandez, 2015).

Grazing intensity near fragment edges, for example, can determine the species composition of that environment. A study comparing matrices composed by grazing with and without cattle showed that the composition of edge tree species was better explained by the presence of cattle than by the matrix structure (Benítez-Malvido et al., 2014). Therefore, identifying the quality of the agricultural matrix is an essential factor to mediate the conservation of natural resources and ecosystem services in fragmented landscapes (Perfecto \& Vandermeer, 2010). 


\section{THE AGRICULTURAL MATRIX IN ITSELF}

The fact that agriculture is considered a vector of environmental degradation (Pascual \& Perrings, 2007; Tscharntke et al., 2005) is mainly due to the industrial agricultural development model initiated in the late $19^{\text {th }}$ century, implemented with the perspective of raising food production levels. This model has spread worldwide and is based on intensive agriculture in external inputs (fertilizers, agrochemicals, genetically improved varieties and mechanization) (Holt-Giménez \& Altieri, 2013). This model adoption ignored many of the environmental peculiarities and the diversity of agriculture forms that were developed in the different continents (Toledo \& Barrera Bassols, 2008).

Although it has raised productivity, this agriculture model has also promoted losses in biodiversity and associated ecosystem services (Butchart et al., 2010). Among the main aggravating factors is the consolidation of simplified matrices which are poor in biodiversity and have low quality of conservation (Didhan et al., 2015; Vandermeer \& Perfecto, 2007). Such impacts on biodiversity have been reported for at least half a century and a classic study was that by Carson (1962), referring to the consequences of using agrochemicals to birds.

Despite this reality, agriculture can be the key for preserving natural resources in fragmented landscapes (Perfecto \& Vandermeer, 2010). Some authors consider that the management forms developed from the agroecological perspective, mainly based on the local sociocultural and environmental reality, could raise biodiversity indices, energy flows, ecological services, and guarantee food production (Gaigher et al., 2015; Gliessman, 2016). The combination of different management practices such as subsistence agriculture, cattle ranching with low pasture densities, extractivism/ logging, agroforestry yards, no-tillage systems and agroforestry provide greater heterogeneity of secondary habitats, increasing the capacity to shelter biodiversity (Haenke et al., 2014; Madeira et al., 2016).

Thus, agricultural matrices can be as important for conservation as remnant areas (Perfecto \& Vandermeer, 1997; Rösch et al., 2015; Tscharntke et al., 2012). The composition and management of the matrices turn them into facilitators or barriers to the species permanence and dispersion in the landscape.
Reducing the use of inorganic inputs such as mineral fertilizers and agrochemicals also facilitates the use and permanence of species in agricultural matrices. Through a meta-analysis, comparing the effects of organic and conventional agriculture on biodiversity, Tuck et al. (2014) show that organic agriculture has increased species richness by about $30 \%$. The authors point out that the increase in the proportion of plowed land was the parameter responsible for increasing the diversity differences between organic and conventional agriculture.

Geiger et al. (2010) emphasize that, among the evaluated agricultural intensification components, the use of agrochemicals (insecticides and fungicides) produced the most negative effect on biodiversity, and also reduced the potential of biological control. Areas managed with organic agriculture and other systems to mitigate the negative effects of intensive agriculture assist in increasing the diversity of wild plant and beetle species. For pollinator species, the effect of organic farming is limited by the increase in the intensity of land use in the environment. This is due to the relationship between local and regional actions and the movement of organisms, which are sensitive to agrochemical application throughout the landscape. Thus, even increasing species diversity at local scale, pollinators can be affected by agrochemical application on other scales, both by the drift of these chemicals and by visitation in those areas (Tuck et al., 2014).

Land-use systems that provide semi-natural habitats present high value for biodiversity (Neumann et al., 2016). These areas have additional features which ensure greater functional connectivity, and thus help to maintain landscape heterogeneity. Neumann et al. (2016) identified that the composition and configuration of matrix habitats helped to explain the community composition of forest carabid beetles. Some systems which maintain arboreal elements in their cultivation form (such as live fences, fruit trees or timber) are characterized as semi-natural, functioning as a refuge environment and connectivity between fragments. Live fences were essential to aid in the dispersal of slow-moving carabid beetles in fragmented landscapes. The authors suggested that some species may persist for decades in the landscape when representative elements from the original habitat are maintained (Neumann et al., 2016).

Agroforestry systems (AFSs), for example, are a management form that integrates agricultural production 
to the permanence and/or management of tree species, increasing the matrix's capacity to house species, meaning to increase their quality. Uezu et al. (2008) evaluated the role of AFSs in the diversity and distribution of birds in Atlantic Forest areas in Southeastern Brazil. AFSs were more important to promote the wealth of generalist species than monoculture areas.

Goulart et al. (2011) verified the habitat usage frequency of five species of frugivorous birds in agroforestry grounds, secondary forest and pastures in Pontal do Paranapanema, Brazil. The authors found that the total habitat usage frequency was higher in the secondary forest for almost all species, except for Amazonas aestiva. However, the number of feeding episodes was higher in agroforestry farms than in forests for all species, with the exception of Cyanocorax chrysops. Only one of the species was observed feeding on pasture areas. The authors state the importance of agroforestry systems as a resource-rich habitat for frugivorous birds. Therefore, matrices consolidated from management strategies and more biodiverse productive systems are an alternative to increase the permeability of the agricultural matrix (Goulart et al., 2011; Uezu et al., 2008).

As highlighted by Birkhofer et al. (2015), matrices with greater heterogeneity over time and space guarantee greater biodiversity in productive areas. For these authors, the composition and configuration of agricultural areas in agricultural landscapes as well as their multiannual dynamics should be considered. In this sense, the habitat/ matrix paradigm in landscapes ecology resulted in few studies in the agricultural areas. This highlights the importance in considering heterogeneity in studies on biodiversity in agricultural landscapes.

In summary, the diversity of production systems and low impact management are key in determining the matrix quality and the heterogeneity of agricultural landscapes. Thus, actions to conserve biodiversity on the landscape scale should also consider the management of areas converted to agriculture, in addition to ensuring that remnant areas of original vegetation remain. These areas help to maintain biodiversity patterns and resource availability over time and space (Benton et al., 2003), since species vary in their response patterns to habitat modification at the local and landscape scales (Pardini et al., 2009).

\section{LANDSCAPE}

The landscape is a complex mosaic of different types of land-use, where the species are not affected only by the size, shape and spatial location of the primary habitat, but also by the structure and composition of the surrounding matrix (Haila, 2002; Kupfer et al., 2006). Thus, conservation of forest cover remnants associated with management of anthropic areas could reduce biodiversity loss and guarantee food production, consolidating sustainable and multifunctional landscapes (Iverson et al., 2014; Perfecto et al., 2009).

Different models have been proposed in the landscape scale in order to reconcile agricultural activities with biodiversity conservation. Two of these models (namely the "land sparing" and the "land sharing" models) have distinct views on the management of agroecosystems and agricultural landscapes, and have become the most influential (Brussaard et al., 2010; Phalan et al., 2011; Tscharntke et al., 2012; Garnett et al., 2013). The first one proposes agriculture intensification based on investment in technologies that increase productivity per unit area, with a reduction in land conversion and/or the allocation of more areas for conservation. On the other hand, the second model is based on biodiversity conservation linked to production, considering the management of more biodiverse production systems adapted to different local realities, highlighting the quality of the agricultural matrix as fundamental for conservation (Tscharntke et al., 2012).

Understanding these two models involves understanding the role of the agricultural matrix in the conservation of biodiversity and ecological services. The "land sparing" system proposes conservation based on forest remnants, ignoring the role of the productive system for this purpose. On the other hand, the "land sharing" system considers the agricultural matrix as fundamental to help the conservation (Phalan et al., 2011; Tscharntke et al., 2012). Despite different understandings about the role of the matrix, as highlighted in previous sections, the landscape is a continuum where the quality of the original habitat and the matrix serves as a facilitator or barrier to the permanence and dispersion of species, rather than the binary habitat/non-habitat perspective (Perfecto \& Vandermeer, 2010). 
In a recent review, Goulart et al. (2016) pointed out that agriculture intensification (using monocrops, transgenics, synthetic inputs, agrochemicals and mechanization) in agricultural landscapes may lead to population declines in the original habitat fragments as it reduces the flow between habitats, as well as local impacts as a consequence of the reduced heterogeneity and the use of agrochemicals, leading to a loss of ecological species and services. This effect may be aggravated in regions where the original habitat proportion is less than 30\%, as in many tropical biodiversity hotspots (e.g. Cerrado and Atlantic Forest). Authors who point to land sparing as more efficient argue that intensification may provide larger original vegetation areas for conservation by virtue of achieving higher productivity per unit area. Despite this, they recognize that this system may be unsustainable for agricultural production itself (Matson et al., 1997; Fischer et al., 2008; Scherr \& McNeely, 2008).

On the other hand, it is recognized that agriculture of lesser intensity and with more incremental diversity in the productive systems could support greater associated biodiversity, along with the maintenance of forest fragments, gallery forests and trees in the agricultural area (Fischer et al., 2008). In some cases, this biodiversity can benefit the food production systems themselves with biological control, pollination and other ecosystem services (Perfecto \& Vandermeer, 2010; Tscharntke et al., 2012) (Figure 2).

It is noted that the main issues of this debate are centered on the need to maintain high levels of original vegetation cover and guarantee food production to meet global demands. The total vegetation cover in landscapes is one of the most important factors for the permanence of species (Melo et al., 2013; Pardini et al., 2009), especially for forest interior specialists (Pardini et al., 2009). Although this is the main argument for the land sparing system, it is noted that agriculture intensification has been happening without causing an increase in forest cover or even reducing deforestation (Goulart et al., 2016). One example is the increase in soybean exports $(282.9 \%$ in the last year), where the productive areas are driven by export demand. In addition, the maintenance of conservation areas in some regions could increase the pressure on others, as in the case of Amazon protection to the detriment of advancing the agricultural frontier in the Cerrado (Goulart et al., 2016).

\section{Biodiversity consevation}

Environmental harms

(e.g., erosion,

\section{Land sparing Low biodiversity greenhouse gas emission,}

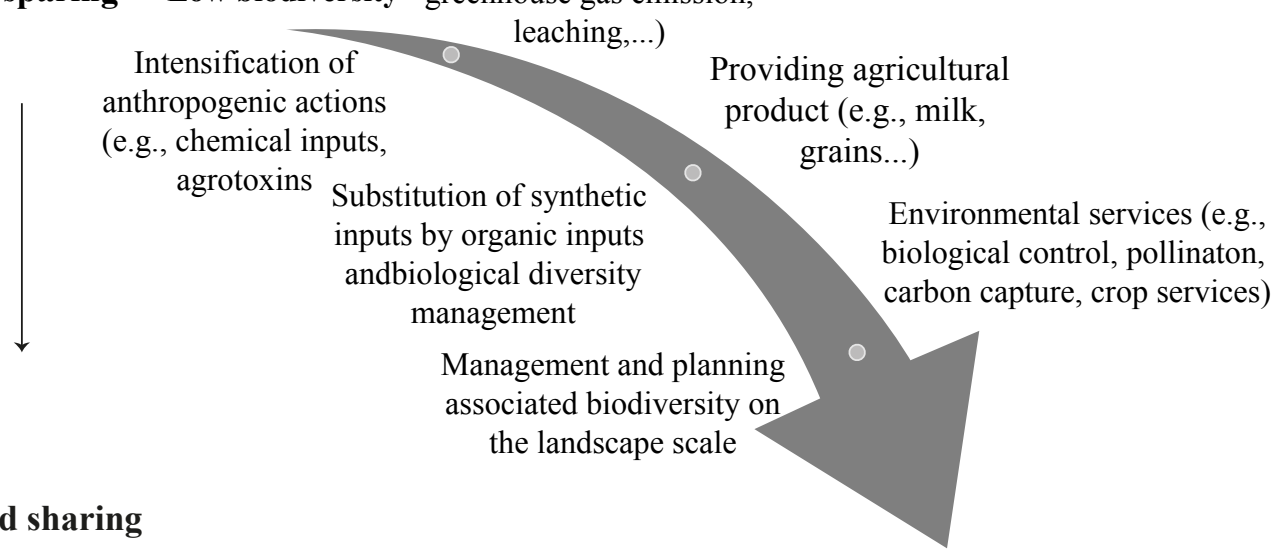

High biodiversity

Figure 2. Relationship between productive systems and the provision of environmental services in land sparing and land sharing systems (Adapted from Tscharntke et al., 2012). 
In addition, some studies have pointed out the potential of ecologically based agriculture for food production. In a work presenting the potential of organic agriculture in the $21^{\text {st }}$ century, Reganold \& Wachter (2016) show that the sale of organic food is growing rapidly, with a 15-fold increase between 1999 and 2013, and with a projection to double between 2013 and 2018. Only 1\% of the world's agricultural land is occupied by organic agriculture, yet these areas contribute significantly to global food supply and still provide multiple benefits for ecological, social and economic services (Reganold \& Wachter, 2016). Although they still produce lower yields per unit area compared to conventional agriculture, they provide equally or more nutritious foods with a reduction in (and even inexistence of) agrochemical wastes.

Although organic farming's role has yet to be explored to establish sustainable farming systems, a single approach would not be able to feed the planet safely. Instead, an integration of other innovative farming systems will be necessary. Nevertheless, a policy approach to minimize barriers to adopt such systems is necessary, since a variety of policy instruments will be needed to facilitate their development and implementation.

In view of the above, it can be said that biodiversity maintenance in fragmented landscapes is associated with habitat heterogeneity (Goulart et al., 2011), since species respond differently to habitat and landscape modification, where a greater number of habitat types is important to increase the resource availability over time and space (Benton et al., 2003). Thus, two aspects seem to be important to support maintaining heterogeneous landscapes: a) the maintenance of original vegetation cover; and b) an increase of biodiversity in the production systems. These aspects can ensure greater biodiversity and the maintenance of ecological services, thereby ensuring higher ecological quality of the matrix and fragments (Figure 3).

Balmford et al. (2012) suggest that transitioning land sparing to land sharing systems could reduce biodiversity if the original vegetation cover were fragmented for association with productive systems, thus moving from a large contingent to a dispersed distribution (Figure 3 ). Thus, they suggest that a better strategy would be to concentrate large blocks of original vegetation where efforts would be concentrated and there would be greater benefits for biodiversity. However, conservation efforts could follow a different course, reconciling the remaining areas and increasing biodiversity in the productive systems, highlighting practices such as: agroforestry, live fences, silvopastoral systems, spontaneous vegetation management, among others (Figure $3 \mathrm{~d}$ ). a)

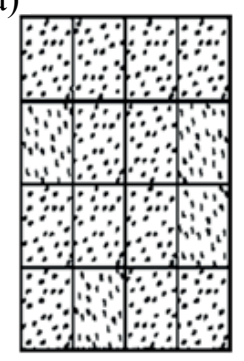

b)

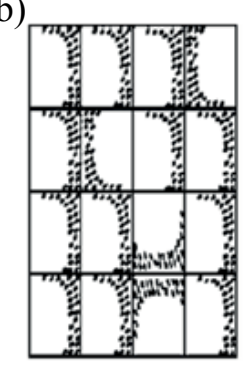

c)

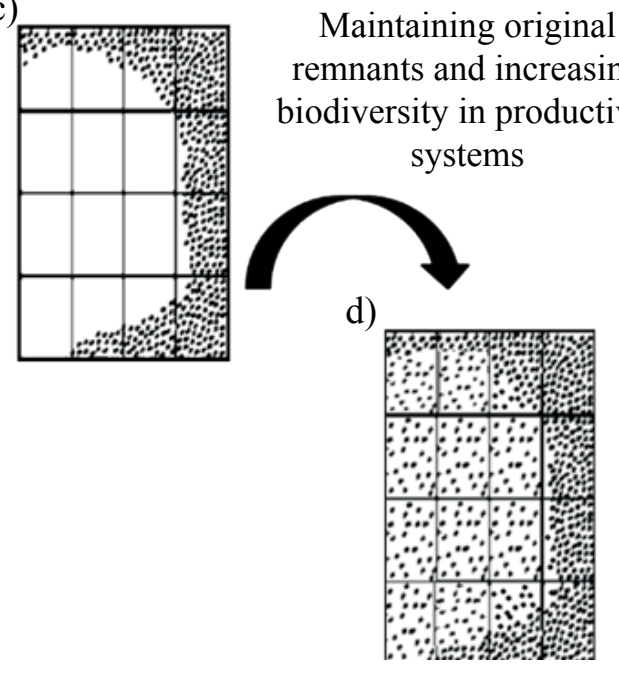

Figure 3. Graphical representation of the different systems (land sparing $b$ and $c$; land sharing $a$ and $d$ ) considering that all figures have the same area; the graphs $b$ and $c$ synthesize land sparing at the local and regional scale; and $a$ the land sharing system where the vegetation cover would be distributed in a dispersed manner; and $d$ increase biodiversity in the productive systems and maintenance of large contingents of natural vegetation. Adapted from Balmford et al. (2012). 
Thus, in addition to the fragment sizes and the levels of total original vegetation cover, the composition of the agricultural matrix is also a determining factor for the species richness in the landscape. Sánchez-de-Jesús et al. (2016) conducted a study with dung beetles in Selva Lacandona in Mexico, and verified that these factors were the main predictors of the beetle community. Landscapes dominated by small fragments with lower total forest cover percentage and matrices composed of open areas had lower species richness, abundance and biomass. The community equability was also smaller in this type of landscape, since there was a loss of rare species. The authors suggest that the loss of forest cover, the reduced size of the fragments and the matrix composition impact the dung beetle species more than the spatial configuration of the forest. Thus, they suggest that conservation initiatives should prioritize reducing deforestation and increasing the matrix heterogeneity adjacent to forest remnants.

Summarily, the results of the studies show that the land sharing system would be able to offer greater capacity to increase the landscape heterogeneity and also guarantee safer food production levels from ecological and social perspectives. However, it is necessary to recognize that local factors such as biological diversity, public policies and investment in studies are necessary to increase agricultural efficiency.

\section{CONCLUSIONS}

The way the agricultural matrix is managed has a direct influence on biodiversity conservation, acting on different spatial scales ranging from the matrix itself, the edge and the interior of the fragments adjacent to it, as well as the landscape in which these systems are inserted. The high mechanization degree, planting of transgenic varieties and the intense use of fertilizers and agrochemicals are among the main factors responsible for the biodiversity losses observed in the forest remnant areas. Despite this, only a minority of the studies conducted consider these parameters and evaluate their effects at different distances of the matrix within forest fragments, as well as under different landscape scales. Therefore, the spillover effect of matrices for forest areas has been largely underestimated. Future studies on habitat fragmentation effects on biodiversity cannot neglect the identity and management of the matrix adjacent to forest remnants. In addition, further studies are necessary to characterize the biodiversity and the capacity of agricultural matrices as a complementary habitat considering different landscape scales.

\section{SUBMISSION STATUS}

Received: 30 May, 2017

Accepted: 26 Oct., 2017

\section{CORRESPONDENCE TO}

\section{Patricia Dias Tavares}

Instituto Federal de Educação, Ciência e Tecnologia de Goiás (IFG Campus Cidade de Goiás), Rua 02, Qd. 10, Lts. 1 a 15, Residencial Bauman, Cep: 76600-000, Cidade de Goiás - Goiás e-mail: padiastavares@gmail.com

\section{REFERENCES}

Balmford A, Green R, Phalan B. What conservationists need to know about farming. Proceedings of the Royal Society of London B: Biological Sciences 2012; 279(1739): 2714-2724. 10.1098/rspb.2012.0515

Barlow J, Lennox GD, Ferreira J, Berenguer E, Lees AC, Mac Nally et al. Anthropogenic disturbance in tropical forests can double biodiversity loss from deforestation. Nature 2016; 535(7610): 144-147. 10.1038/nature18326

Benítez-Malvido J, Martínez-Falcón AP, Dáttilo W, Del Val E. Diversity and network structure of invertebrate communities associated to Heliconia species in natural and human disturbed tropical rain forests. Global Ecology and Conservation 2014; 2: 107-117. 10.1016/j.gecco.2014.08.007

Benton TG, Vickery JA, Wilson JD. Farmland biodiversity: is habitat heterogeneity the key? Trends in Ecology \& Evolution 2003; 18(4): 182-188. 10.1016/S0169-5347(03)00011-9

Birkhofer K, Diehl E, Andersson J, Ekroos J, Früh-Müller A, Machnikowski F et al. Ecosystem services-current challenges and opportunities for ecological research. Frontiers in Ecology and Evolution 2015; 2(87): 1-12. $10.3389 /$ fevo.2014.00087

Blitzer EJ, Dormann CF, Holzschuh A, Klein AM, Rand TA, Tscharntke T. Spillover of functionally important organisms between managed and natural habitats. Agriculture, Ecosystems \& Environment 2012; 146(1): 34-43. 10.1016/j.agee.2011.09.005

Brussaard L, Caron P, Campbell B, Lipper L, Mainka S, Rabbinge $R$ et al. Reconciling biodiversity conservation and food security: scientific challenges for a new agriculture. 
Current Opinion in Environmental Sustainability 2010; 2(1): 34-42. 10.1016/j.cosust.2010.03.007

Butchart SH, Walpole M, Collen B, Van Strien A, Scharlemann JP, Almond RE et al. Global biodiversity: indicators of recent declines. Science 2010; 328(5982): 1164-1168. 10.1126/science. 1187512

Cadenasso ML, Pickett STA. Linking forest edge structure to edge function: mediation of herbivore damage. Journal of Ecology 2000; 88(1): 31-44. 10.1046/j.1365-2745.2000.00423.x

Campos RC, Hernández MI. Changes in the dynamics of functional groups in communities of dung beetles in Atlantic forest fragments adjacent to transgenic maize crops. Ecological Indicators 2015; 49: 216-227. 10.1016/j.ecolind.2014.09.043

Carson R. Silent spring. Boston: Houghton Mifflin Harcourt; 1962.

Dallimer M, Rouquette JR, Skinner AM, Armsworth PR, Maltby LM, Warren PH et al. Contrasting patterns in species richness of birds, butterflies and plants along riparian corridors in an urban landscape. Diversity and Distributions 2012; 18(8): 742-753. 10.1111/j.1472-4642.2012.00891.x

D’Anunciação PER, Silva MFV, Ferrante L, Assis DS, Casagrande T, Coelho AZG et al. Forest fragments surrounded by sugar cane are more inhospitable to terrestrial Amphibian abundance than fragments surrounded by pasture. International Journal of Ecology 2013; 2013: 1-8. 10.1155/2013/183726

Didham RK, Barker GM, Bartlam S, Deakin EL, Denmead LH, Fisk LM et al. Agricultural intensification exacerbates spillover effects on soil biogeochemistry in adjacent forest remnants. PloS One 2015; 10(1): e0116474. 10.1371/ journal.pone.0116474

Didham RK, Lawton JH. Edge structure determines the magnitude of changes in microclimate and vegetation structure in tropical forest fragments. Biotropica 1999; 1999: 17-30. 10.1111/j.1744-7429.1999.tb00113.x

Driscoll MJL, Donovan TM. Landscape context moderates edge effects: nesting success of wood thrushes in central New York. Conservation Biology 2004; 18(5): 1330-1338. 10.1111/j.1523-1739.2004.00254.x

Dupouey JL, Dambrine E, Laffite JD, Moares C. Irreversible impact of past land use on forest soils and biodiversity. Ecology 2002; 83(11): 2978-2984. 10.2307/3071833

Ewers RM, Didham RK. Continuous response functions for quantifying the strength of edge effects. Journal of Applied Ecology 2006; 43(3): 527-536. 10.1111/j.1365-2664.2006.01151.x

Fagan WF, Cantrell RS, Cosner C. How habitat edges change species interactions. The American Naturalist 1999; 53(2): 165-182. 10.1086/303162

Fahrig L. Rethinking patch size and isolation effects: the habitat amount hypothesis. Journal of Biogeography 2013; 40(9): 1649-1663. 10.1111/jbi.12130
Fischer J, Brosi B, Daily GC, Ehrlich PR, Goldman R, Goldstein J et al. Should agricultural policies encourage land sparing or wildlife-friendly farming? Frontiers in Ecology and the Environment 2008; 6(7):380-385. 10.1890/070019

Fischer J, Lindenmayer D. Beyond fragmentation: the continuum model for fauna research and conservation in human-modified landscapes. Oikos 2006; 112(2): 473480. 10.1111/j.0030-1299.2006.14148.x

Flinn KM, Marks PL. Agricultural legacies in forest environments: tree communities, soil properties, and light availability. Ecological Applications 2007; 17(2): 452463. 10.1890/05-1963

Foley JA, DeFries R, Asner GP, Barford C, Bonan G, Carpenter SR et al. Global consequences of land use. Science 2005; 309(5734): 570-574. 10.1126/science.1111772

Food and Agriculture Organization of the United Nations FAO. The state of the world's land and water resources for food and agriculture: managing systems at risk. Rome: FAO; 2011.

Food and Agriculture Organization of the United Nations - FAO. State of the World's Forests 2016: forests and agriculture: land-use challenges and opportunities. Rome: FAO; 2016.

Forman RT. Some general principles of landscape and regional ecology. Landscape Ecology 1995; 10(3): 133-142. 10.1007/BF00133027

Forman RT, Godron M. Landscape ecology. New York: John Wiley \& Sons; 1986.

Frost CM, Didham RK, Rand TA, Peralta G, Tylianakis JM. Community-level net spillover of natural enemies from managed to natural forest. Ecology 2015; 96(1): 193-202. 10.1890/14-0696.1

Gaigher R, Pryke JS, Samways MJ. High parasitoid diversity in remnant natural vegetation, but limited spillover into the agricultural matrix in South African vineyard agroecosystems. Biological Conservation 2015; 186: 69-74. 10.1016/j.biocon.2015.03.003

Gardner TA, Caro T, Fitzherbert EB, Banda T, Lalbhai P. Conservation value of multiple-use areas in East Africa. Conservation Biology 2007; 21(6): 1516-1525. 10.1111/j.1523-1739.2007.00794.x

Garnett T, Appleby MC, Balmford A, Bateman IJ, Benton, TG, Bloomer $P$ et al. Sustainable intensification in agriculture: premises and policies. Science 2013; 341(6141): 33-34. 10.1126/science.1234485

Geiger F, Bengtsson J, Berendse F, Weisser WW, Emmerson M, Morales MB et al. Persistent negative effects of pesticides on biodiversity and biological control potential on European farmland. Basic and Applied Ecology 2010; 11(2): 97-105. 10.1016/j.baae.2009.12.001

Gibbs HK, Ruesch AS, Achard F, Clayton MK, Holmgren P, Ramankutty NA et al. Tropical forests were the primary sources of new agricultural land in the 1980s and 1990s. 
Proceedings of the National Academy of Sciences 2010; 107(38): 16732-16737. 10.1073/pnas.0910275107

Gliessman S. How to leave industrial agriculture behind by shifting food systems toward agroecology. Agroecology and Sustainable Food Systems 2016; 40(8): 757-758. $10.1080 / 21683565.2016 .1200170$

Goulart FF, Carvalho-Ribeiro S, Soares-Filho B. Farmingbiodiversity segregation or integration? Revisiting land sparing versus land sharing debate. Journal of Environmental Protection 2016; 7(7): 1016-1032. 10.4236/jep.2016.77090

Goulart FF, Vandermeer J, Perfecto I, Matta-Machado RP. Frugivory by five bird species in agroforest home gardens of Pontal do Paranapanema, Brazil. Agroforestry Systems 2011; 82(3): 239-246. 10.1007/s10457-011-9398-Z

Haenke S, Kovács-Hostyánszki A, Fründ J, Batáry P, Jauker B, Tscharntke $T$ et al. Landscape configuration of crops and hedgerows drives local syrphid fly abundance. Journal of Applied Ecology 2014; 51(2): 505-513. 10.1111/1365-2664.12221

Haila Y. A conceptual genealogy of fragmentation research: from island biogeography to landscape ecology. Ecological Applications 2002; 12(2): 321-334. 10.1890/1051-0761(2002)012[0321:ACGOFR]2.0.CO;2

Harper KA, Macdonald SE, Burton PJ, Chen J, Brosofske $\mathrm{KD}$, Saunders SC et al. Edge influence on forest structure and composition in fragmented landscapes. Conservation Biology 2005; 19(3): 768-782. 10.1111/j.1523-1739.2005.00045.x

Hobbs RJ, Harris JA. Restoration ecology: repairing the earth's ecosystems in the new millennium. Restoration Ecology 2001; 9(2): 239-246. 10.1046/j.1526100x.2001.009002239.x

Holt-Giménez E, Altieri MA. Agroecology, food sovereignty, and the new green revolution. Agroecology and Sustainable Food Systems 2013; 37(1): 90-102. 10.1080/10440046.2012.716388

Honnay O, Verheyen K, Butaye J, Jacquemyn H, Bossuyt B, Hermy M. Possible effects of habitat fragmentation and climate change on the range of forest plant species. Ecology Letters 2002; 5(4): 525-530. 10.1046/j.14610248.2002.00346.x

Hosonuma N, Herold M, De Sy V, De Fries RS, Brockhaus $\mathrm{M}$, Verchot $\mathrm{L}$ et al. An assessment of deforestation and forest degradation drivers in developing countries. Environmental Research Letters 2012; 7(4): e044009. 10.1088/1748-9326/7/4/044009

Hurst ZM, McCleery RA, Collier BA, Fletcher RJ Jr, Silvy NJ, Taylor PJ et al. Dynamic edge effects in small mammal communities across a conservation-agricultural interface in Swaziland. PLoS One 2013; 8(9): e74520. 10.1371/ journal.pone.0074520

International Service for the Acquisition of Agri-Biotech Applications - ISAAA. 20th anniversary (1996-2015) of the commercialization of biotech crops. 2015 [cited 2016 Nov. 21]. Available from: https://bit.ly/2nduCOV

Iverson L, Echeverria C, Nahuelhual L, Luque S. Ecosystem services in changing landscapes: an introduction. Landscape Ecology 2014; 29(2): 181-186. 10.1007/s10980-014-9993-2

Kennedy CM, Marra PP. Matrix mediates avian movements in tropical forested landscapes: inference from experimental translocations. Biological Conservation 2010; 143(9): 2136-2145. 10.1016/j.biocon.2010.05.025

Kleijn D, Snoeijing IJ. Field boundary vegetation and the effects of agrochemical drift: botanical change caused by low levels of herbicide and fertilizer. Journal of Applied Ecology 1997; 34(6): 1413-1425. 10.2307/2405258

Kohler F, Verhulst J, Van Klink R, Kleijn D. At what spatial scale do high-quality habitats enhance the diversity of forbs and pollinators in intensively farmed landscapes? Journal of Applied Ecology 2008; 45(3): 753-762. 10.1111/j.1365-2664.2007.01394.x

Kupfer JA, Malanson GP, Franklin SB. Not seeing the ocean for the islands: the mediating influence of matrix-based processes on forest fragmentation effects. Global Ecology and Biogeography 2006; 15(1): 8-20. 10.1111/j.1466822X.2006.00204.x

Laliberté E, Tylianakis JM. Cascading effects of long-term land-use changes on plant traits and ecosystem functioning. Ecology 2012; 93(1): 145-155. 10.1890/11-0338.1

Laurance WF. Theory meets reality: how habitat fragmentation research has transcended island biogeographic theory. Biological Conservation 2008; 141(7): 1731-1744. 10.1016/j.biocon.2008.05.011

Laurance WF, Cochrane MA. Synergistic effects in fragmented landscapes. Conservation Biology 2001; 15(6): 1488-1489. 10.1046/j.1523-1739.2001.01088.x

Laurance WF, Lovejoy TE, Vasconcelos HL, Bruna EM, Didham RK, Stouffer PC et al. Ecosystem decay of Amazonian forest fragments: a 22-year investigation. Conservation Biology 2002; 16(3): 605-618. 10.1046/j.15231739.2002.01025.x

Laurance WF, Nascimento HE, Laurance SG, Andrade A, Ewers RM, Harms KE et al. Habitat fragmentation, variable edge effects, and the landscape-divergence hypothesis. PLoS One 2007; 2(10): e1017. 10.1371/journal.pone.0001017

Laurance WF, Sayer J, Cassman KG. Agricultural expansion and its impacts on tropical nature. Trends in Ecology \& Evolution 2014; 29(2): 107-116. 10.1016/j. tree.2013.12.001

Lindenmayer DB, Franklin JF. Conserving forest biodiversity: a comprehensive multiscaled approach. Washington, DC: Island Press; 2002.

Lôbo D, Leão T, Melo FP, Santos AM, Tabarelli M. Forest fragmentation drives Atlantic forest of northeastern Brazil 
to biotic homogenization. Diversity and Distributions 2011; 17(2): 287-296. 10.1111/j.1472-4642.2010.00739.x

MacArthur RH, Wilson EO. An equilibrium theory of insular zoogeography. Evolution 1963; 17(4): 373-387. $10.2307 / 2407089$

MacArthur RH, Wilson EO. The theory of island biogeography. Princeton: Princeton University Press; 1967.

Madeira F, Tscharntke T, Elek Z, Kormann UG, Pons X, Rösch V et al. Spillover of arthropods from cropland to protected calcareous grassland: the neighbouring habitat matters. Agriculture, Ecosystems \& Environment 2016; 235: 127-133. 10.1016/j.agee.2016.10.012

Magura T. Carabids and forest edge: spatial pattern and edge effect. Forest Ecology and Management 2002; 157(1-3): 23-37. 10.1016/S0378-1127(00)00654-X

Marshall EJP, Moonen AC. Field margins in northern Europe: their functions and interactions with agriculture. Agriculture, Ecosystems \& Environment 2002; 89(1): 5-21. 10.1016/S0167-8809(01)00315-2

Matson PA, Parton WJ, Power AG, Swift MJ. Agricultural intensification and ecosystem properties. Science 1997; 277(5325): 504-509. 10.1126/science.277.5325.504

Meire RO, Lee SC, Yao Y, Targino AC, Torres JPM, Harner T. Seasonal and altitudinal variations of legacy and current-use pesticides in the Brazilian tropical and subtropical mountains. Atmospheric Environment 2012; 59: 108-116. 10.1016/j.atmosenv.2012.05.018

Melo FP, Arroyo-Rodríguez V, Fahrig L, Martínez-Ramos M, Tabarelli M. On the hope for biodiversity-friendly tropical landscapes. Trends in Ecology \& Evolution 2013; 28(8): 462-468. 0.1016/j.tree.2013.01.001

Monadjem A, Garcelon DK. Nesting distribution of vultures in relation to land use in Swaziland. Biodiversity \& Conservation 2005; 14(9): 2079-2093. 10.1007/s10531-004-4358-9

Montero-Castaño A, Vilà M. Impact of landscape alteration and invasions on pollinators: a meta-analysis. Journal of Ecology 2012; 100(4): 884-893. 10.1111/j.13652745.2012.01968.x

Murcia C. Edge effects in fragmented forests: implications for conservation. Trends in Ecology \& Evolution 1995; 10(2): 58-62. 10.1016/S0169-5347(00)88977-6

Neumann JL, Griffiths GH, Hoodless A, Holloway GJ. The compositional and configurational heterogeneity of matrix habitats shape woodland carabid communities in wooded-agricultural landscapes. Landscape Ecology 2016; 31(2): 301-315. 10.1007/s10980-015-0244-y

Öckinger E, Lindborg R, Sjödin NE, Bommarco R. Landscape matrix modifies richness of plants and insects in grassland fragments. Ecography 2012; 35(3): 259-267. 10.1111/j.1600-0587.2011.06870.x
Pardini R, Faria D, Accacio GM, Laps RR, Mariano-Neto E, Paciencia MLB et al. The challenge of maintaining Atlantic forest biodiversity: a multi-taxa conservation assessment of specialist and generalist species in an agroforestry mosaic in southern Bahia. Biological Conservation 2009; 142(6): 1178-1190. 10.1016/j.biocon.2009.02.010

Pascual U, Perrings C. Developing incentives and economic mechanisms for in situ biodiversity conservation in agricultural landscapes. Agriculture, Ecosystems \& Environment 2007; 121(3): 256-268. 10.1016/j.agee.2006.12.025

Pe’er G, van Maanen C, Turbé A, Matsinos YG, Kark S. Butterfly diversity at the ecotone between agricultural and semi-natural habitats across a climatic gradient. Diversity and Distributions 2011; 17(6): 1186-1197. 10.1111/j.1472-4642.2011.00795.x

Peres CA. Synergistic effects of subsistence hunting and habitat fragmentation on Amazonian forest vertebrates. Conservation Biology 2011; 15(6): 1490-1505. 10.1046/j.1523-1739.2001.01089.x

Perfecto I, Vandermeer J. The agroecological matrix as alternative to the land-sparing/agriculture intensification model. Proceedings of the National Academy of Sciences 2010; 107(13): 5786-5791. 10.1073/pnas.0905455107

Perfecto I, Vandermeer J, Hanson P, Cartín V. Arthropod biodiversity loss and the transformation of a tropical agro-ecosystem. Biodiversity and Conservation 1997; 6(7): 935-945. 10.1023/A:1018359429106

Perfecto I, Vandermeer J, Wright A. Nature's matrix: linking agriculture, conservation and food sovereignty. London: Earthscan; 2009.

Phalan B, Onial M, Balmford A, Green RE. Reconciling food production and biodiversity conservation: land sharing and land sparing compared. Science 2011; 333(6047): 1289-1291. 10.1126/science.1208742

Prevedello JA, Vieira MV. Does the type of matrix matter? A quantitative review of the evidence. Biodiversity and Conservation 2010; 19(5): 1205-1223. 10.1007/s10531009-9750-Z

Ramankutty N, Evan AT, Monfreda C, Foley JA. Farming the planet: 1. Geographic distribution of global agricultural lands in the year 2000. Global Biogeochemical Cycles 2008; 22(1): GB1003. 10.1029/2007GB002952

Reganold JP, Wachter JM. Organic agriculture in the twenty-first century. Nature Plants 2016; 2: e15221. 10.1038/nplants.2015.221

Ries L, Fletcher RJ Jr, Battin J, Sisk TD. Ecological responses to habitat edges: mechanisms, models, and variability explained. Annual Review of Ecology, Evolution, and Systematics 2004; 35: 491-522. 10.1146/annurev. ecolsys.35.112202.130148

Rodenhouse NL, Best LB, O'Connor RJ, Bollinger EK. Effects of agricultural practices and farmland structures. In: Martin TE, Finch DM, editors. Ecology 
and management of neotropical migratory birds. New York: Oxford University Press; 1995. p. 269-293.

Rösch V, Tscharntke T, Scherber C, Batáry P. Biodiversity conservation across taxa and landscapes requires many small as well as single large habitat fragments. Oecologia 2015; 179(1): 209-222. 10.1007/s00442-015-3315-5

Sánchez-de-Jesús HA, Arroyo-Rodríguez V, Andresen E, Escobar F. Forest loss and matrix composition are the major drivers shaping dung beetle assemblages in a fragmented rainforest. Landscape Ecology 2016; 31(4): 843-854. 10.1007/s10980-015-0293-2

Santos-Barrera G, Urbina-Cardona, JN. The role of the matrix-edge dynamics of amphibian conservation in tropical montane fragmented landscapes. Revista Mexicana de Biodiversidad 2011 [cited 2019 June 4]; 82(2): 679-687. Available from: https://bit.ly/2KsT7X4

Saunders DA, Hobbs RJ, Margules CR. Biological consequences of ecosystem fragmentation: a review. Conservation Biology 1991; 5(1): 8-32. 10.1111/j.1523-1739.1991.tb00384.x

Scherr SJ, McNeely JA. Biodiversity conservation and agricultural sustainability: towards a new paradigm of 'ecoagriculture' landscapes. Philosophical Transactions of the Royal Society of London B: Biological Sciences 2008; 363(1491): 477-494. 10.1098/rstb.2007.2165

Tabarelli M, Aguiar AV, Girão LC, Peres CA, Lopes AV. Effects of pioneer tree species hyperabundance on forest fragments in northeastern Brazil. Conservation Biology 2010; 24(6): 1654-1663. 10.1111/j.1523-1739.2010.01529.x

Toledo VM, Barrera-Bassols N. La memoria biocultural: la importancia ecológica de las sabidurías tradicionales. Barcelona: Icaria; 2008.

Tscharntke T, Klein AM, Kruess A, Steffan-Dewenter I, Thies C. Landscape perspectives on agricultural intensification and biodiversity: ecosystem service management. Ecology Letters 2005; 8(8): 857-874. 10.1111/j.1461-0248.2005.00782.x

Tscharntke T, Tylianakis JM, Rand TA, Didham RK, Fahrig L, Batary P et al. Landscape moderation of biodiversity patterns and processes: eight hypotheses. Biological Reviews 2012; 87(3): 661-685. 10.1111/j.1469-185X.2011.00216.x
Uezu A, Beyer DD, Metzger JP. Can agroforest woodlots work as stepping stones for birds in the Atlantic forest region? Biodiversity and Conservation 2008; 17(8): 1907 1922. 10.1007/s10531-008-9329-0

Uzêda MC, Fidalgo ECC, de Sousa Moreira RV, Fontana A, Donagemma GK. Eutrofização de solos e comunidade arbórea em fragmentos de uma paisagem agrícola. Pesquisa Agropecuária Brasileira 2016; 51(9): 1120-1130. 10.1590/S0100-204X2016000900011

Vandermeer J, Perfecto I. The agricultural matrix and a future paradigm for conservation. Conservation Biology 2007; 21(1): 274-277. 10.1111/j.1523-1739.2006.00582.x

Vanreusel W, Van Dyck H. When functional habitat does not match vegetation types: a resource-based approach to map butterfly habitat. Biological Conservation 2007; 135(2): 202-211. 10.1016/j.biocon.2006.10.035

Verburg PH, Van Asselen S, Van der Zanden EH, Stehfest E. The representation of landscapes in global scale assessments of environmental change. Landscape Ecology 2013; 28(6): 1067-1080. 10.1007/s10980-012-9745-0

Viveiros de Castro EB, Fernandez FAS. Determinants of differential extinction vulnerabilities of small mammals in Atlantic Forest fragments in Brazil. Biological Conservation 2004; 119: 73-80. 10.1016/j.biocon.2003.10.023

Walker S, Wilson JB, Steel JB, Rapson GL, Smith B, King $\mathrm{WM}$ et al. Properties of ecotones: evidence from five ecotones objectively determined from a coastal vegetation gradient. Journal of Vegetation Science 2003; 14(4): 579-590. 10.1111/j.1654-1103.2003.tb02185.x

Wermelinger B, Flückiger PF, Obrist MK, Duelli P. Horizontal and vertical distribution of saproxylic beetles (Col., Buprestidae, Cerambycidae, Scolytinae) across sections of forest edges. Journal of Applied Entomology 2007; 131(2): 104-114. 10.1111/j.1439-0418.2006.01128.x

Wuyts K, De Schrijver A, Vermeiren F, Verheyen K. Gradual forest edges can mitigate edge effects on throughfall deposition if their size and shape are well considered. Forest Ecology and Management 2009; 257(2): 679-687. 10.1016/j.foreco.2008.09.045 